Article

\title{
What Should SMEs Consider to Introduce Environmentally Innovative Products to Market?
}

\author{
Daegyu Yang(1) \\ School of Management, Kyung Hee University, Seoul 02447, Korea; daegyu@khu.ac.kr
}

Received: 25 January 2019; Accepted: 18 February 2019; Published: 20 February 2019

\begin{abstract}
In recent years, companies are challenged not only to develop market competencies but also to deal with environmental issues. Unlike larger companies equipped with abundant resources and sustainable capabilities, small- and medium-sized enterprises (SMEs) are under relatively constrained conditions to effectively deal with environmental concerns as well as market demands. This study attempts to examine a set of potential factors by which SMEs can overcome such limited conditions and bring novel and environmentally beneficial products to market through their innovative activities. Organization theories, such as organizational learning, social network theory, and new-institutional theory, provide a theoretical framework for this study that SMEs may utilize their resources and capabilities from internal, external, and institutional domains. The hypotheses are tested using the Korea Innovation Survey 2010. The analyses show that the likelihood of the market introduction of new and environmentally innovative products is increased not only when an SME makes more monetary investments on internal innovative activities and experiences more success in general innovation activities, but also when an SME inputs more monetary investments into the search for technological knowledge from the outside and utilizes more diverse external information sources. Interestingly, the findings demonstrate that monetary support from the government do not have significant impacts on an SME's environmental innovation, while a non-monetary technological support system operated by government raises the likelihood of the market introduction of new and environmentally innovative products. Theoretical contributions and managerial implications are discussed.
\end{abstract}

Keywords: small- and medium-sized enterprises (SMEs); environmental innovation; new product introduction; natural-resource-based view (NRBV); organizational learning; social networks; knowledge management; new-institutional theory

\section{Introduction}

Today, companies are unprecedentedly challenged by a growing magnitude of environmental problems everywhere in the world. Aside from the global pressures from market competitions, today's companies are required by various stakeholders to facilitate environmentally sustainable strategic activities [1-3]. It seems that without formulating and implementing an effective set of strategic action plans to deal with such critical concerns of the stakeholders, companies would fail to maintain their existing positions in the market. In particular, among the stakeholders surrounding a company, consumers are rapidly emerging as the environmental guardians who seriously consider the company's environmental philosophy when they make decisions on a product purchase [4]. Other things being equal, it is obvious that consumers prefer products manufactured with environmental considerations. To meet the environmental requirements from their consumers, companies should develop a unique set of resources and capabilities, especially to introduce new products that nicely incorporate environmental concerns in its functionalities on time. That is, an effective and timely introduction of environmentally innovative products to market is a crucial strategic action that a company 
should choose as a strategic option to effectively deal with not only market competitions but also environmental concerns [2,3].

However, to implement such a strategic action is not always easy for companies. Adding environmental elements to the existing organizational activities requires additional efforts to build resources and capabilities to be used as the fundamental basis of competitive advantages. Environmental innovation tends to be riskier as it requires much more commitment and takes a long time to celebrate returns from environmental innovations [1,5]. Even further, it seems obvious that the request for environmental innovations begins to be globally legitimized by authoritative institutions, so companies cannot simply delay the adaptation of environmental innovation to their operation. In particular, absorbing the pressures of environmental concerns into concrete strategic actions would be more difficult for small- and medium-sized enterprises (SMEs) than the large, longstanding companies, as they tend to have more strategic constraints imposed on them in terms of resources and capabilities than their counterparts [6]. Nevertheless, it is apparently imperative that SMEs invent new designs and create novel products in order to reverse the risks presented by the rising requests for environmental innovation into opportunities to overcome seemingly unfavorable market competitions. Given this, this study aims at suggesting crucial factors for SMEs to effectively incorporate environmental issues into their products by placing theoretical emphases on an extended resource-based view, a firm-standing view for a company's strategic actions $[2,3,7,8]$.

The traditional resource-based view of the strategic management area suggests that to develop and maintain sustainable competitive advantages, companies have to deliberately develop their unique resources by which they increase the capabilities to outperform the competitors within their boundaries $[7,8]$. However, when it comes with environmental concerns, companies should open their eyes wide and turn their focuses to the outside because the environmental concerns tend to appear from the outside and environmental issues by nature exist as crucial externalities. As Hart points out [2], the traditional resource-based view does not pay sufficient attention to the interaction between a company and its natural environment as the theoretical focuses tend to remain within the boundary. Furthermore, incorporation of externally raised environmental issues is not very possible when companies try to deal with the issues with knowledge only developed within their boundary. To cope with the environmental concerns brought by various outside stakeholders such as consumers, established institutions, or other external market audiences, it is inevitable for companies to reach out to external resources and capabilities. More specifically, SMEs, which tend to be structurally limited in their resources and capabilities, should pay more careful attentions to an effective and efficient means of dealing with the environmental innovations [9]. Despite the urgency derived from the rising concerns for environmental innovations, quite a few studies have been so far conducted, even fewer with the focuses on SMEs' environmental innovation. Furthermore, little has been known particularly about the factors on the market introduction of environmentally innovative new products with SME focuses.

In this study, to broaden the spectrum of the current research about SMEs' environmental innovations, three distinctive domains are explored in which SMEs should allocate their resources and obtain chances to build their capabilities (internal, external, and institutional domains) by paying great attention to relevant organization theories such as organizational learning, social networks, and new-institutional theory, respectively. Organizational learning addresses how an organization interprets its past experiences and develops new knowledge by which it can effectively deal with the newly emerging issues $[10,11]$. I suggest that organizational learning helps understand how an SME can effectively use its innovation-related experiences to incorporate environmental concerns. Social network perspectives provide rich insights about the effective and efficient access to knowledge located outside a company through well-established relationships with external partners [12-14]. Based on social network perspective, I argue that to achieve environmental innovations, SMEs should pay great attention to the diverse links with external partners possessing relevant knowledge. As environmental issues involve the government as a crucial stakeholder which may enforce various regulatory and facilitative systems on private companies, I suggest that new-institutional theory 
helps understand how SMEs strategically behave under the environmental pressures driven by the government $[15,16]$. Although not exclusive, the framework suggested in this study covers a significant set of relevant domains that influence SMEs' efforts to produce meaningful outcomes from environmentally innovative activities in comprehensive ways. As an empirical research, this study examines the factors articulated from the suggested organization theories on SMEs' environmentally innovative outcomes. By using a reliable data source, the Korea Innovation Survey 2010 Manufacturing Industry, this study attempts to test the influential factors from each domain on the outcomes of environmental innovation and to discuss the SMEs' environmental innovations over the analyses. In doing so, this study contributes not only to the environmental innovation literature but also the SMEs' strategic management research by suggesting the factors the SMEs should carefully consider to meet both the demands from the market as well as the demands about environmental issues.

In sum, the contributions that this paper makes are as follows: First, this paper fills the research gap in the current literature of SMEs' environmental innovation by emphasizing the significance of considering various, yet distinctive, domains in which solid theoretical insights from organization theories can be effectively applied [6]. By examining three distinctive domains with three theoretical frameworks developed in the area of organization theory, this study provides more detailed explanations about SMEs' environment-related strategies. Next, this paper provides strategic implications that help SMEs cope with the rapidly emerging environmental concerns from various stakeholders, especially in a constantly competitive market environment. It helps the decision-makers of SMEs understand how they allocate their strategic attentions to each domain to enhance their chances of successfully introducing environmentally innovative new products. Lastly, this paper shows governmental policymakers a right direction for environmental policies by examining which types of governmental support actually leads the SMEs to the expected outcomes.

\section{Hypothesis Development}

To effectively deal with the increasing market demands for environmental problems, companies not only have to properly build a set of resources, but also accumulate relevant knowledge about the environmental issues. In his attempts to link strategic managements and environmental issues in an elaborated theoretical framework, Hart points out that the invention of new products that properly incorporate the environmental issues must be centrally set as a crucial strategic plan [2]. Moreover, Hart's suggestion about product stewardship is more valuable as the development of environmentally innovative products is a most effective strategy that companies can choose to preemptively respond to the rising environmental problems. In particular, the environmentally innovative products enable SMEs to proactively deal with the emerging environmental demands as well as the present economic and social concerns because the development of environmentally innovative products may provide SMEs with rather ambidextrously functioning resources to solve challenges that emerge simultaneously from multiple sites. Given this, among many strategic options to deal with environmental problems, the option focusing on the market introduction of environmentally innovative products should a priority for SMEs, and consequently it will serve as a key generator of sustained competitive advantages.

In particular, SMEs should make considerate decisions on allocating their resources, as they are under more constrained conditions than larger companies. Therefore, a closer theoretical examination about SME-specific factors is necessary. Unlike larger companies that have been located in better market positions with a greater amount of resources to utilize, SMEs often need to make more deliberate strategic decisions about resource allocation to effectively compete with their larger counterparts in market. As the demands of environmental innovation require additional resource allocations and capability developments than existing practices, SMEs therefore have to carefully allocate their strategic and managerial attentions to the decision-making processes regarding such additional responsibilities based on solid theoretical foundations. In developing hypotheses, three theoretical perspectives are adopted: First, an organizational learning perspective can help SMEs 
enhance their internal capabilities to cope with the environmental issues in their innovation-related activities by providing insights about how and where they should focus on innovation-related experiences [11,17]. Next, while a large company tends to be closely linked with its sister companies of a larger business group to which it belongs and to obtain knowledge benefits from its group partners, an SME (generally an independent business entity) tends to be structurally constrained in terms of the knowledge exchanging relationships. A social network theory regarding knowledge exchanges addresses how SMEs can reach out to external partners from whom they can obtain relevant knowledge for environmental issues [12,18]. Lastly, a new-institutional theory gives insights about how an SME may collaborate with the government, a legitimate stakeholder regarding environmental issues, by describing how a coercive external pressure can be effectively dealt with $[15,16,19]$. In sum, my hypotheses about SMEs' strategic actions about environment innovation are developed by adopting the theoretical perspectives suggested in the area of organization theory.

\subsection{The Internal Domain}

To develop innovatively new products requires a significant amount of investment on research and development activities within the company boundaries. An environmental innovation is by nature not simply a part or a by-product of overall technological innovation, but a separate element that requires additional management. That is, a company has to draw significant attentions to novel ideas and technologies along with an appropriate amount of supports and investments [20-22]. For example, a company needs to install an independent institution to focus on research and development activities alongside its current production-related routines. Such an institution can be utilized not only to investigate the company's existing production processes, but also to search for new opportunities necessary for innovations. In this regard, organizational learning literature suggests that to effectively reach a satisfactory degree of innovation, an organization must focus both on exploitation and exploration in balance [23]. For an environmental innovation, an effective balancing is very necessary as it is something that requires more specific attentions because it has to deal with concerns derived from various external stakeholders. When it comes to environmental innovation, balancing between these two different modes of innovation-related activities becomes much harder, as many scholars in the organizational learning area point out that these two modes are often contradictory when there exist attention allocation issues. That is, operating an independently $R \& D$ focused institution that takes a separate role of advancing innovations is very necessary for SMEs to focus on very special activities of producing environmentally innovative new products on time, and it requires additional investments. Obviously, a company also has to make investments on various tangible assets such as buildings, new machineries, or technological equipment to support the R\&D-related activities. Therefore, an SME with internal investments, especially in tangible or intangible assets within its boundary, is more likely to accelerate environmental innovations.

In addition, an SME that has achieved technological innovations in other areas is likely to properly respond to the environmental demands in market. According to the organizational learning literature, successful experiences in a certain domain of organizational activities tend to spill over to the others $[17,24]$. Specifically, companies that pour great strategic attention into innovation activities within boundaries and achieve a significant degree of successful innovations by themselves are very likely to accumulate abundant experiential knowledge to use for environmental innovations additionally given by the external stakeholders. This view is supported by Cohen and Levinthal's idea of absorptive capacity, that organizations having successfully experienced the development of innovative knowledge in a specific area may be more able to expand the breadth of their competence into related domains [17]. Accordingly, SMEs that have poured significant amounts of strategic attention to innovation across broader domains within their boundaries are very likely to accumulate and utilize the relevant knowledge to incorporate environmental demands in the designs and productions of environmentally innovative products. Therefore, the following hypotheses are proposed: 
Hypothesis 1a. SMEs having more monetary investments in innovation activities are more likely to achieve environmental innovation in terms of new product market introduction.

Hypothesis 1b. SMEs having succeeded in more innovations within their boundaries are more likely to achieve environmental innovation in terms of new product market introduction.

\subsection{The External Domain}

To produce significant outcomes especially in innovation-related activities, companies cannot simply focus on the internal exploitation of their own knowledge. Companies often have to reach out to the knowledge bases located outside of their boundaries. In particular, as environmental issues tend to contain many externalities that various external stakeholders require from various points of view, companies must turn their attentions to the outside to effectively cope with such demands. Despite relatively constrained conditions with limited resources, SMEs inevitably should make sufficient investments in the searching activities to look for the relevant knowledge that reside in the outside to incorporate the rising demands for environmental concerns. That is, it is prerequisite for SMEs to prepare resources for external search for the knowledge relevant to the environmental problems. In this regard, the more investments an SME makes for the external search, the more likely it produces the intended outcomes.

As for environmental innovation, it has been used as a dominant activity to exploratorily search for knowledge and information from the outside. To acquire a proper set of information, companies should try to collaborate with knowledgeable external partners. A social network perspective that especially focuses on knowledge transfer suggests that diverse and possibly non-redundant knowledge can be obtained from building collaborative relationships with external institutions [25,26]. According to this perspective, network ties generally function as an important channel through which valuable information and knowledge flow [27-29]. Reaching out to the diverse sources of information through collaborative relationships therefore often helps companies deal with environmental issues that are often characterized as regulatory pressures. Through such collaborative relationships developed across diverse knowledgeable partners, crucial knowledge and information that help the focal organization develop new technologies of environmental innovation can be effectively acquired. Therefore, diverse external institutions such as independent research and development institutes, commercial labs, consultants, or suppliers of equipment and components can be useful for SMEs to effectively collect the knowledge required for environmental innovations.

Recent studies in the area of knowledge management also emphasize the importance of diverse external information sources in organizations' innovation performances [30-32]. According to these studies, the innovation outcomes are closely associated with the external partners that function as the source of uncodified tacit knowledge as well as codified knowledge [30]. The literature also argues that establishing relationships with diverse external partners such as clients, suppliers, or universities not only expands the width of knowledge but also encourages the focal SMEs to recognize the importance of innovations [32]. Taken together, an SME establishing collaborative relationships with diverse external information providers tends to have higher chances of successfully introducing environmentally innovative products to the market. Therefore, the following hypotheses are proposed:

Hypothesis 2a. SMEs having more monetary investments in external searching activities are more likely to achieve environmental innovation in terms of new product market introduction.

Hypothesis 2b. SMEs utilizing diverse information sources through external collaborative partners are more likely to achieve environmental innovation in terms of new product market introduction. 


\subsection{The Institutional Domain}

Today, environmental issues are often enacted by an authoritative institution, i.e., government. The Paris Agreement, adopted by consensus among the member nations of the United Nations Framework Convention on Climate Change (UNFCCC) in 2015, is a representative example that the governments of each country have to set target plans to mitigate the problems of climate change and to apply the plans to all industries within their border. Even before this agreement was signed, many nations including Korea had already begun to effectuate such environment-related legislations on industries, and Korea is also not exceptional. Under such regulatory conditions, most companies have to comply with the environmental regulations. That is, the governmental involvement in the environmental problems over all industries works as a powerful institutional pressure on every company. According to the institutional theory of organizations, the pressure related to environmental issues is often regarded as a coercive pressure to which companies must effectively comply $[15,16,19]$. To deal with the world-wide consensus, many governments are currently implementing policies to encourage companies, through either regulation or facilitation, to quickly comply with the institutional pressures. In such institutional conditions, companies are sometimes provided with tax reduction or financial support when they apply for governmental regulatory guidance. Companies that are supported by the government in such ways are more likely to feel pressure to comply with the regulations and accelerate the environmental innovations as quickly as possible [33]. Therefore, companies financially supported by the government with regard to environmental issues can more effectively reach the point that they introduce environmentally innovative products to market.

Aside from financial support, the government also provides non-monetary support systems such as technological support to companies in various forms. Companies are often encouraged by the government to innovate their production processes to meet global standards of environmental issues by applying for government-driven technological support. Receiving such governmental technological support would function as institutional pressure for the recipient companies to show a satisfactory degree of environmental outcomes in many respects. Furthermore, regardless of such institutional pressures, receiving relevant knowledge from governmental support would contribute to the actual outcomes because resources for environmental innovations constantly flow into the recipient companies through effective policies of the government, one of the most involved stakeholders concerned with the companies' environmental outcomes. Therefore, the following hypotheses are proposed:

Hypothesis 3a. SMEs receiving more monetary supports from the government are more likely to achieve environmental innovation in terms of new product market introduction.

Hypothesis 3b. SMEs utilizing more non-monetary technological support given by the government are more likely to achieve environmental innovation in terms of new product market introduction.

Figure 1 depicts the research model of the study in which the market introduction of environmentally innovative new products is affected by factors identified from three domains (internal, external, and institutional) of SMEs. 


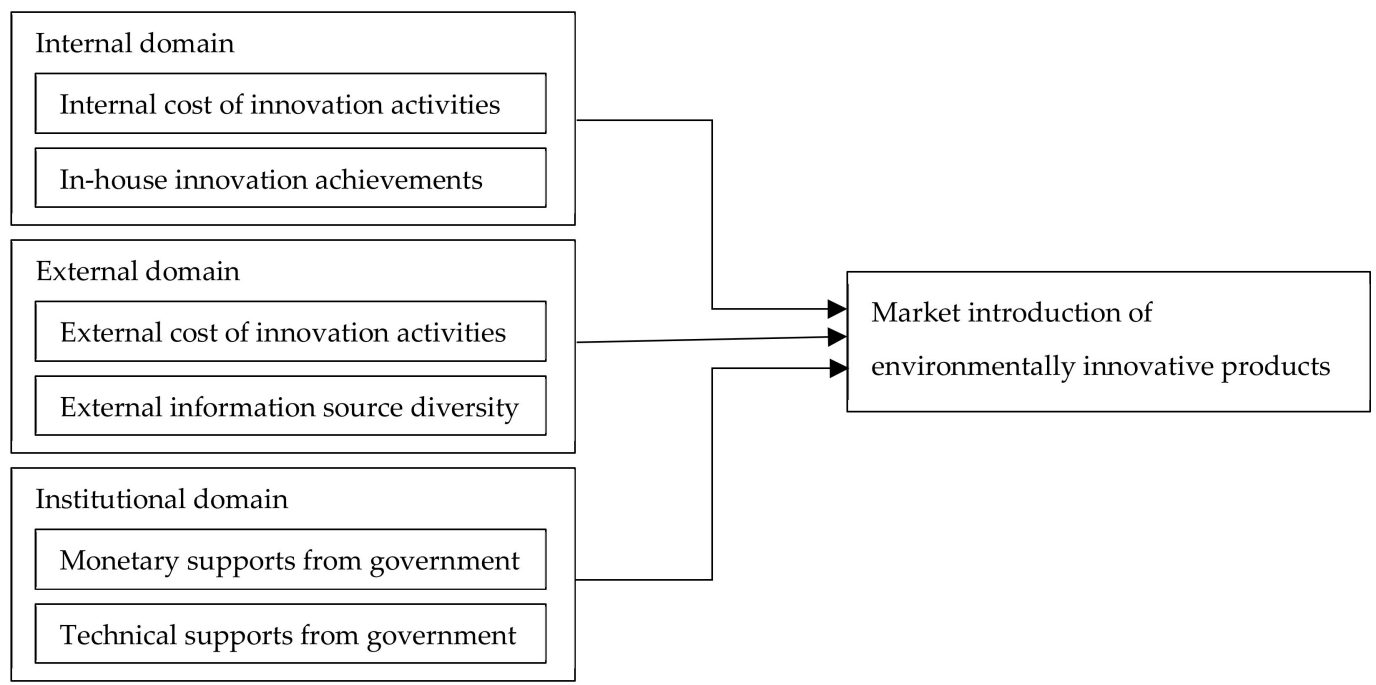

Figure 1. Research model.

\section{Methods}

\subsection{Data}

The "Korean Innovation Survey (KIS) 2010: Manufacturing Industry" was used as the primary data source to test the hypotheses [34]. This survey is conducted biannually by the Science and Technology Policy Institute (STEPI), a representative research institute run by the Korean government in Seoul, Korea. As an authoritative national survey that investigates the innovation activities of private companies in Korea, the KIS collects detailed information about the innovation activities of private companies of Korea in a highly systematic manner, and develops question items based on the European Statistical Office (EUROSTAT)'s "Community Innovation Survey (CIS)," which is designed based on the Organization for Economic Cooperation and Development (OECD)'s Oslo Manual. As the data collected through the CIS is used as an official data source for the European Union (EU) to formulate the policies for companies' innovative activities, the KIS data is also utilized by the Korean government as a credible data source to develop the innovation-related policies for companies. Owing to such reliable features, a growing number of recent innovation-related studies have used the KIS data as a main empirical data source [9,35-38].

STEPI conducted the KIS on the manufacturing industry as a preliminary test in 1996 for the first time. After some preliminary implementation tests, the KIS was adopted as an official survey of organizations' innovation activities in 2008 and it has been conducted biannually on a regular basis to date. Among the KIS datasets collected from 2008 to 2016, the KIS 2010 is especially valuable for the study of organizations' environmental innovations because it is the only dataset that includes a special section for green and environmental innovations [36]. No other KIS datasets, before or after, included this special section for environmental innovation activities. For this reason, the KIS 2010 is very suitable for testing the hypotheses in which several factors on environmental innovation are to be empirically tested; it was also adopted as the research data by recent studies investigating environmental innovations of Korean manufacturing companies [36,38,39]. The KIS 2010 was therefore chosen particularly for this analysis among the KIS datasets accumulated so far. According to STEPI's report, the sample size of the KIS 2010: Manufacturing Industry was 41,485 manufacturing companies located in Korea. Through a stratified random sampling procedure from the industries that fall into the 24 two-digit "Korean Standard Industry Code (KSIC) (10-33)" [34], 3925 companies were chosen as the survey sample, and 3497 companies were officially classified as small- and medium-sized enterprises (SMEs) among the whole sample for the KIS 2010: Manufacturing Industry. However, some observations are excluded due to nonresponses, so the actual sample size used in the analysis becomes 3261 after excluding observations that have missing values in the variables used in analysis. 


\subsection{Measurements}

\subsubsection{Dependent Variable}

In this study, the dependent variable is the market introduction of novel products providing environmental benefits for the consumers. To construct the dependent variable, the response to the KIS 2010 question, "During the three years from 2007 to 2009, did your company introduce new goods that are technologically innovative?" was used first. Then, the response to the question, "During the three years from 2007 to 2009, did your company provide environmental benefits from the after sales use of a good by the end user?" was used. Under this second question, there are three specific categories of environmental benefits: "reduced energy use," "reduced air, water, soil, or noise pollution," and "improved recycling of product after use." In case that the company not only answered "yes" to the first question about the market introduction of technologically new product, but also answered "yes" at least to one sub-categories of the second question about environmental benefit provision, it was considered that a company introduced technologically new products that provided environmental benefits for the consumers to the market. By following this procedure, a binary variable was constructed indicating whether a company introduced technologically new products that provided environmental benefits for the consumers to the market during the observation period. 277 companies in the sample fell into such a case.

\subsubsection{Independent Variables}

For the internal factors by which a company may increase the likelihood of introducing environmentally beneficial new products, the variable of internal cost for innovations was constructed as follows: To measure the monetary resources that were input to the internal innovation-related activities, the amount of expenditure from 2007 to 2009 that a respondent company reported it provided for (1) "in-house R\&D activities," (2) "acquisition of machinery, equipment," and (3) "software, and extra innovation activities such as job trainings" was used. The companies in the sample answered this question by providing the estimated cost of the asked activities in millions of Korean Won (KRW), and the aggregated amount of the expenditure for internal resources was used. To mitigate potential problems derived from the high degree of skewness, the logarithm of the variable was used in the analyses.

To measure the company's innovation-related capabilities, the response to the question, "During the three years from 2007 to 2009, who developed the innovation?" was used. The KIS 2010 classifies technological innovations into four distinctive domains: product, process, organizational, and marketing innovation; the question was asked under the assumption that the company achieved significant innovation in each domain. The questions are asked with the following choices: (1) "your enterprise," (2) "your enterprise together with other enterprises or institutions," or (3) "mainly other enterprises or institutions." It was considered that the respondent company achieved in-house innovations if the company answered the first item of "your enterprise" and construct the in-house innovation achievement as a count variable indicating how many domains the company achieved innovation in by itself. For example, if a company achieved product and marketing innovation, it is coded as two. Therefore, this variable ranges from 0 to 4 .

As for external factors influencing the market introduction of environmentally beneficial new product, the variable was constructed as follows: To measure the monetary resources that were input to the internal innovation-related activities, the amount of expenditure for the innovation activities from 2007 to 2009 for (1) "purchase of external R\&D" and (2) "acquisition of external knowledge" was used. This information was obtained from the response to the question, "Provide the estimated amount of expenditure for each activity (in a million KRW)." These two expenditures used for the external techniques and capabilities were aggregated to be used as a single independent variable of external cost for innovations for the analyses. As prior examination of the distributional characteristics of 
the variable alarmed the high degree of skewness to the left side, the logarithm transformation was applied in the actual analyses.

To measure the diversity of external information sources for innovation activities, the response to the question, "During the three years from 2007 to 2009, how important to your enterprise's innovation activities were each of the following information sources? (1) suppliers of equipment, materials, components, or software, (2) clients or customers, (3) competitors or other enterprises in your sector, (4) consultant, commercial labs, or private R\&D institutes, (5) professional and industry associations, (6) universities or other higher education institutions, (7) government or public research institutes, (8) conferences, trade fairs, or exhibitions, and (9) scientific journals and trad/technical publications" was used. Each external information source was first asked if it was used or not, and then the extent of importance was asked with a five point scale if it was used as an external information source for the company. Based on the responses to this question, the measure of the variable was constructed as follows:

$$
\text { Diversity of external information sources }=1-\sum_{\mathrm{i}}^{9} p_{i}^{2} \text {, }
$$

where $i$ refers to each category of nine different external information sources, and $p$ refers to the proportion of a weighted importance of an external information source to those of all external information sources [40]. This variable is included in the analyses along with a dummy variable indicating a company which does not use external information sources at all.

The last type of variable that may influence a company's environmental innovation is that which is related to the government, one of the most influential institutions that encourages manufacturing companies to focus on environmental issues. As mentioned earlier, the Korean government is highly concerned about the environmental issues. Therefore, it formulates and implements a variety of environmental policies, either regulatory or facilitative. To measure the governmental financial supports that a company received, the response to the question, "During the three years from 2007 to 2009, how much did your company received tax reduction from the development of environmental technology (in a million KRW)?" and the response to another question, "During the three years from 2007 to 2009, how much did your company received governmental funds for the development of environmental technology (in a million KRW)?" were used. Based on the responses to each question, two variables were developed separately, as the characteristics of these governmental monetary-based supports were distinctive to each other. To reduce the skewness, the logarithm-transformed version of the variables in the analyses was used.

In addition to the monetary support from the government, the Korean government also provides various non-monetary technological support to increase innovation capabilities. The KIS 2010 included a question, "During the three years from 2007 to 2009, did you use each of the following supports provided by the government? (1) Participation in government-driven R\&D projects, (2) governmental provision of technological supports, (3) governmental provision of technological information, (4) governmental provision of technological and training staffs, (5) participation in governmental procurements, and (6) marketing supports by government." Based on the response to this question, a count variable was constructed indicating how many government-driven support systems a company participated in; the range of the variable is thus between 0 and 6 .

\subsubsection{Control Variables}

In addition to the independent variables, other factors that may influence the market introduction of environmentally innovative new products were included as control variables in the analysis. First, the industry dummy variables were included in the analysis. All in all, 24 different manufacturing industries were identified based on the two-digit Korean Standard Industry Code (KSIC) and included in in the analysis. Next, the company's age was included in the analysis as elapsed years from the year of company's foundation. Third, the company's size was controlled for based on the literature that larger companies tend to be more active in environmental innovation activities [38,41] by including 
two variables: the number of employees and the annual sales (in millions of KRW). These two variables were all logarithm-transformed to reduce the skewness problems. Forth, whether a company is a listed company or not was included as a dummy variable because publicly traded companies tend to be more susceptible to their reputation regarding innovation outcomes. In Korea, two separate stock exchange markets are operated: "Korea Exchange (KRX)" and "Korean Securities Dealers Automated Quotations (KOSDAQ)." Out of 3261 companies in the sample, 216 companies were listed on either KRX or KOSDAQ (approximately 6.7\%). Fifth, the number of patent applications during the observation period was included, as the patent application represents the extent to which a company is capable of technological innovation [38,42]. This variable was also logarithm-transformed to mitigate the skewness problems. Sixth, the average lifespan of the products of company was included in the analysis, as the market introduction of new products are likely to be influenced by the lifespan of existing products. The response to the question, "How long is the lifespan of your main products on average (in month)?" was used to construct the product lifespan variable. Lastly, the number of the employees working for research and development activities was included, as such R\&D focusing employees are known as the powerhouse of innovations.

\subsubsection{Model}

As the dependent variable of this study was a binary variable indicating whether a company introduced new products with environmental benefits to market, the hypotheses was tested by using logistic regression analysis.

\section{Results}

The descriptive statistics of the variables used in the analysis are presented in Table 1 . As mentioned earlier, out of 3261 SMEs in the sample, 277 SMEs introduced new products with environmental benefits for the end-users during the observation period from 2007 to 2009. In the SMEs used in the analysis, only about $8.5 \%$ introduced environmentally innovative new products to market during the observation period.

Table 1. Descriptive Statistics.

\begin{tabular}{ccccc}
\hline Variables & Mean & S.D. & Min. & Max. \\
\hline Product market introduction & 0.085 & 0.279 & 0 & 1 \\
Age (in year) & 15.089 & 10.686 & 3 & 67 \\
ln (number of employees) & 3.768 & 1.070 & 2.303 & 8.162 \\
ln (annual sales) & 9.020 & 1.537 & 3.296 & 13.903 \\
Listed company (dummy) & 0.066 & 0.249 & 0 & 1 \\
ln (patent applications) & 0.388 & 0.770 & 0 & 5.209 \\
Average product lifespan (in month) & 383.747 & 452.61 & 0.1 & 998 \\
ln (employees for R\&D) & 0.164 & 2.108 & -2.303 & 5.823 \\
ln (internal cost for innovations) & 2.572 & 4.415 & -2.303 & 12.084 \\
In-house innovation achievements & 0.909 & 1.193 & 0 & 4 \\
In (external cost for innovations) & -0.140 & 3.311 & -2.303 & 9.91 \\
Diversity of external information sources & 0.401 & 0.399 & 0 & 0.889 \\
No external information (dummy) & 0.440 & 0.496 & 0 & 1 \\
ln (tax reduction by government) & 0.559 & 1.623 & 0 & 9.543 \\
ln (monetary supports by government) & 1.089 & 2.285 & 0 & 12.161 \\
Use of technological supports by government & 0.989 & 1.981 & 0 & 6 \\
\hline
\end{tabular}

Notes: $N=3261$; industrial code dummies are not reported due to the space limitations.

Table 2 shows the pairwise correlations between the variables included in the analysis. A total of 24 dummy variables were also included indicating Korean Standard Industry Code (KSIC) in the analysis, but these dummy variables were not reported in Tables 1 and 2 because of space limitations. Table 2 shows that each independent variable of interest had fairly strong positive 
relationships with the dependent variable, as expected. Two interesting findings from the pairwise correlation analysis are noteworthy: First, a longer product lifespan resulted in lower chances of environmentally innovative products market introduction. Next, an SME using no external information sources was unlikely to introduce new products with environmental innovations. According to additional data examination, out of 1435 SMEs that did not use external information sources at all during the observation period, only $8 \mathrm{SMEs}$ were found to have introduced such products.

Table 2. Pairwise correlations between variables.

\begin{tabular}{|c|c|c|c|c|c|}
\hline Variables & 1. & 2. & 3. & 4. & 5. \\
\hline \multicolumn{6}{|l|}{ 1. Product market introduction } \\
\hline 2. Age (in year) & 0.070 & & & & \\
\hline 3. $\ln$ (number of employees) & 0.158 & 0.347 & & & \\
\hline 4. $\ln$ (annual sales) & 0.164 & 0.359 & 0.798 & & \\
\hline 5. Listed company (dummy) & 0.083 & 0.259 & 0.363 & 0.384 & \\
\hline 6. $\ln$ (patent applications) & 0.258 & 0.066 & 0.275 & 0.274 & 0.258 \\
\hline 7. Average product lifespan (in month) & -0.123 & -0.041 & -0.114 & -0.092 & -0.049 \\
\hline 8. $\ln ($ employees for R\&D) & 0.277 & 0.228 & 0.513 & 0.513 & 0.304 \\
\hline 9. $\ln$ (internal cost for innovations) & 0.270 & 0.172 & 0.398 & 0.418 & 0.255 \\
\hline 10. In-house innovation achievements & 0.305 & 0.119 & 0.259 & 0.266 & 0.151 \\
\hline 11. $\ln$ (external cost for innovations) & 0.263 & 0.129 & 0.336 & 0.332 & 0.226 \\
\hline 12. Diversity of external information sources & 0.285 & 0.150 & 0.359 & 0.373 & 0.197 \\
\hline 13. No external information use (dummy) & -0.252 & -0.136 & -0.331 & -0.355 & -0.186 \\
\hline 14. $\ln$ (tax reduction by government) & 0.179 & 0.121 & 0.251 & 0.257 & 0.194 \\
\hline 15. $\ln$ (monetary supports by government) & 0.219 & 0.026 & 0.214 & 0.200 & 0.187 \\
\hline 16. Use of technological supports by government & 0.270 & 0.088 & 0.264 & 0.25 & 0.176 \\
\hline Variables (continued) & 6. & 7. & 8. & 9. & 10. \\
\hline 7. Average product lifespan (in month) & -0.217 & & & & \\
\hline 8. $\ln ($ employees for R\&D) & 0.502 & -0.341 & & & \\
\hline 9. In (internal cost for innovations) & 0.437 & -0.309 & 0.825 & & \\
\hline 10. In-house innovation achievements & 0.378 & -0.261 & 0.602 & 0.581 & \\
\hline 11. $\ln$ (external cost for innovations) & 0.449 & -0.238 & 0.552 & 0.598 & 0.421 \\
\hline 12. Diversity of external information sources & 0.425 & -0.326 & 0.759 & 0.736 & 0.591 \\
\hline 13. No external information use (dummy) & -0.410 & 0.331 & -0.797 & -0.798 & -0.586 \\
\hline 14. $\ln$ (tax reduction by government) & 0.322 & -0.140 & 0.371 & 0.353 & 0.250 \\
\hline 15. In (monetary supports by government) & 0.437 & -0.182 & 0.454 & 0.453 & 0.287 \\
\hline 16. Use of technological supports by government & 0.428 & -0.206 & 0.471 & 0.433 & 0.333 \\
\hline Variables (continued) & 11. & 12. & 13. & 14. & 15. \\
\hline 12. Diversity of external information sources & 0.543 & & & & \\
\hline 13. No external information use (dummy) & -0.522 & -0.890 & & & \\
\hline 14. $\ln$ (tax reduction by government) & 0.356 & 0.310 & -0.279 & & \\
\hline 15. $\ln$ (monetary supports by government) & 0.448 & 0.434 & -0.389 & 0.454 & \\
\hline 16. Use of technological supports by government & 0.484 & 0.481 & -0.406 & 0.443 & 0.609 \\
\hline
\end{tabular}

Notes: $N=3261$; industrial code (KSIC) dummies are not reported due to the space limitations.

Table 3 displays the results from the logistic regression analyses of the market introduction of environmentally innovative new products. Model 1 is the baseline model of the analyses in which the control variables alone are included. Interestingly, the result of Model 1 shows that nether the organization size nor organizational age have statistically meaningful influence, particularly on the environmental innovation measured as the market introduction of new products with environmental innovation. It seems that while technological innovation capacity of organizations is influenced by the organizational size and age in general, environmental innovations are quite unique areas for the organization that requires other attention. These findings indirectly imply that SMEs may not be constricted by limited capacity or experience in the industry to which they belong if they pay careful attention to the innovative activities regarding environmental issues. As these control 
variables are consistently insignificant in all models, it can also be interpreted that the independent variables introduced in the hypotheses have relatively strong influences on SMEs' environmental innovation outcomes. In contrast, a couple of variables reflecting SMEs' technological capacity have strong influences: the number of patent applications and the number of R\&D specializing employees. The number of patent applications is often considered as a proxy to capture the extent to which SMEs strive to make additional innovations. The consistent significance of this variable in all models therefore suggests that by devoting more efforts to innovation activities, an SME is likely to find more opportunities to effectively incorporate environmental concerns into their final products. In addition, the number of employees specializing in research and development was consistently positive at significant level across all the models reported in Table 3. Such a finding implies that employing knowledgeable workers is very important if SMEs seriously care about environmental innovations. In sum, these findings suggest that environmental innovations tend to be more effectively developed when SMEs pay more attention to technological innovation activities.

Table 3. Results of Logistic Regression.

\begin{tabular}{|c|c|c|c|c|}
\hline Variables & Model 1 & Model 2 & Model 3 & Model 4 \\
\hline (Constant) & $\begin{array}{c}-3.176^{* *} \\
(0.732)\end{array}$ & $\begin{array}{c}-4.193 * * \\
(0.762)\end{array}$ & $\begin{array}{c}-4.031^{* *} \\
(0.796)\end{array}$ & $\begin{array}{c}-3.447^{* * *} \\
(0.743)\end{array}$ \\
\hline Age & $\begin{array}{c}0.004 \\
(0.007)\end{array}$ & $\begin{array}{c}0.004 \\
(0.007)\end{array}$ & $\begin{array}{c}0.004 \\
(0.007)\end{array}$ & $\begin{array}{c}0.005 \\
(0.007)\end{array}$ \\
\hline $\ln$ (number of employees) & $\begin{array}{l}-0.108 \\
(0.128)\end{array}$ & $\begin{array}{l}-0.058 \\
(0.135)\end{array}$ & $\begin{array}{l}-0.078 \\
(0.132)\end{array}$ & $\begin{array}{l}-0.132 \\
(0.130)\end{array}$ \\
\hline ln (annual sales) & $\begin{array}{c}0.048 \\
(0.090)\end{array}$ & $\begin{array}{c}0.035 \\
(0.095)\end{array}$ & $\begin{array}{c}0.061 \\
(0.092)\end{array}$ & $\begin{array}{c}0.076 \\
(0.092)\end{array}$ \\
\hline Listed company (dummy) & $\begin{array}{l}-0.463 \\
(0.235)\end{array}$ & $\begin{array}{c}-0.408 \\
(0.239)\end{array}$ & $\begin{array}{l}-0.366 \\
(0.234)\end{array}$ & $\begin{array}{c}-0.476 \\
(0.236)\end{array}$ \\
\hline ln (patent applications) & $\begin{array}{c}0.358 * * \\
(0.074)\end{array}$ & $\begin{array}{c}0.305^{* *} \\
(0.075)\end{array}$ & $\begin{array}{c}0.286^{* *} \\
(0.076)\end{array}$ & $\begin{array}{c}0.269 * * \\
(0.077)\end{array}$ \\
\hline Average product lifespan & $\begin{array}{l}-0.000 \\
(0.000)\end{array}$ & $\begin{array}{l}-0.000 \\
(0.000)\end{array}$ & $\begin{array}{l}-0.000 \\
(0.000)\end{array}$ & $\begin{array}{l}-0.000 \\
(0.000)\end{array}$ \\
\hline $\ln ($ employees for R\&D) & $\begin{array}{c}0.595^{* *} \\
(0.070)\end{array}$ & $\begin{array}{c}0.323 \text { ** } \\
(0.086)\end{array}$ & $\begin{array}{c}0.311^{* *} \\
(0.086)\end{array}$ & $\begin{array}{c}0.520 \text { ** } \\
(0.071)\end{array}$ \\
\hline No external information (dummy) & & & $\begin{array}{l}-0.817 \\
(0.513)\end{array}$ & \\
\hline ln (internal cost for innovations) & & $\begin{array}{c}0.139 * * \\
(0.031)\end{array}$ & & \\
\hline In-house innovation achievements & & $\begin{array}{c}0.413^{* *} \\
(0.058)\end{array}$ & & \\
\hline ln (external cost for innovations) & & & $\begin{array}{c}0.077^{* *} \\
(0.020)\end{array}$ & \\
\hline Diversity of external information sources & & & $\begin{array}{l}1.532 * * \\
(0.441)\end{array}$ & \\
\hline ln (tax reduction by government) & & & & $\begin{array}{c}0.004 \\
(0.033)\end{array}$ \\
\hline ln (monetary supports by government) & & & & $\begin{array}{c}0.022 \\
(0.030)\end{array}$ \\
\hline Use of technological supports by government & & & & $\begin{array}{c}0.149 * * \\
(0.033)\end{array}$ \\
\hline Chi-square & 358.181 & 443.889 & 429.468 & 389.461 \\
\hline pseudo R-square & 0.189 & 0.234 & 0.227 & 0.205 \\
\hline
\end{tabular}

Notes: $N=3261 ;{ }^{*} p<0.5,{ }^{* *} p<0.01$; standard errors are in parentheses; industrial code (KSIC) dummies are included but not reported due to the space limitations.

In Model 2, to test Hypotheses $1 \mathrm{a}$ and $1 \mathrm{~b}$, logarithm-transformed internal cost of innovation and the in-house innovation achievement were added, respectively. The result first shows that the more an SME used its resources on internal innovative activities on a monetary basis, the more likely it introduced environmentally innovative new products to the markets, 
as the coefficient of the logarithm-information internal cost of innovation is positive at a significant level. Thus, Hypothesis 1a is supported by the analysis. Additionally, as the coefficient of in-house innovation achievement is positive at a significant level, Hypothesis $1 \mathrm{~b}$ (that an SME that has accomplished other general innovative activities within the boundary is more likely to introduce environmentally innovative new products to market) is supported. In sum, the two variables indicating the SMEs' resources and activities in internal domains are significant influencers on the market introduction of environmentally innovative products, which can be interpreted that an SME with more focused investments on innovation activities internally is likely to enable the market introduction of environmentally innovative products effectively.

In Model 3, to test Hypotheses 2a and 2b, the external cost of innovation activities as its logarithm-transformed version and the diversity of external information sources in the analysis was added, respectively. The coefficient of the logarithm-transformed external cost of innovation is significantly positive, therefore supporting Hypothesis 2a. That is, the more an SME inputs monetary resources into activities to bring external resources about innovations, the more likely it produces environmentally innovative products and introduces the products to market. Likewise, the coefficient of the diversity of external information sources is significant and positive in Model 2, which shows that an SME utilizing diverse information sources from outside is more likely to achieve the environmental innovations measured as the chances of introduction new products with environmentally innovative features. Therefore, Hypothesis $2 b$ is also supported. The findings from Model 2 therefore present that an SME is likely to effectively reach environmental innovations when it invests more financially on innovation-related activities and attempts to acquire more knowledge from diverse external information sources.

With respect to the effects of an SME's receiving support from the government monetarily or technologically, Model 4 includes the logarithm-transformed tax reduction and monetary support as well as the use of technological support driven by the government in the analysis. Both the tax reduction and the monetary support from the government do not have statistically significant effects on the market production of environmentally innovative new products, which does not support Hypothesis 3a. However, the use of innovation-related technological supports from the government had significant and positive impacts on the market introduction of environmentally innovative new products, as the coefficient of the variable is significant and positive in the analysis reported in Model 4, providing strong support for the prediction that the more non-monetary technological support an SME receives from the government, the more likely it successfully introduces environmentally innovative new products to market. Therefore, Hypothesis $3 \mathrm{~b}$ is supported by the results. The findings from Model 4 show that while monetary support from the government does not have a meaningful impact, technological support from the government has significant impacts on the environmental innovation outcomes measured by the market introduction of environmentally innovative new products.

\section{Discussion}

While studies of SMEs' environmental innovations have been long called for in broad organization research areas, quite limited numbers of studies exist. As an earlier empirical study using a reliable data source collected in well-designed data collection schemes by an authoritative research institution, this paper investigates critical factors from three domains (internal, external, and institutional) in which SMEs may devote their efforts to properly respond to the strong market demands regarding environmental concerns.

The hypotheses, drawn from three organization theories that are all relevant to an organization's competitive advantages in the environmental innovations, predict that not only do monetary investments focusing on the acquisition of relevant knowledge affect a higher chance of introducing environmentally innovative new products to market in three domains, but also a properly developed set of activities of accessing relevant knowledge in three domains also affect it. All in all, the analyses support the hypotheses, except for Hypothesis 3a, the prediction that monetary supports for 
innovations from government would positively affect an SME's chances of introducing environmentally innovative products.

The findings show that an SME that arranges a nicely prepared monetary resources to focus on research and development activities about innovations inside as well as outside is able to properly respond to environmental demands from the market. Under highly competitive market conditions, SMEs may be constrained to strive only for coping with the existing market competition based on economic viewpoints, therefore failing to incorporate the rapidly emerging environmental issues that cannot be ignored or delayed. Considering the results of analyses in which market sales included as a control variable do not have significant impacts on the environmental innovation in market, while both internal and external cost of innovation have strong effects, SMEs' extra attention to the innovation-related investments are highly critical in terms of strategic action plans [43]. That is, an SME preparing constantly for innovations can build its own resources and capabilities to deal with environmental issues raised by consumers.

In addition, the results of the analyses confirm the importance of SMEs' efforts to constantly try to make and acquire the relevant knowledge about innovations, when it comes with environmental innovations $[17,24,44]$. Innovation-focused strategic plans may enable an SME to experience a sufficient and satisfactory extent of innovative successes by which it also can result in successes in the area of environmental innovation. Organizational learning theories consistently support that cumulated experiences of success lead to subsequent ones, and success in one area also spills over to success in other areas $[10,11]$. That is, to accomplish a significant level of success in environmental innovations, SMEs should constantly try to elaborate their routines in other areas as well. Consistent with such arguments from organizational learning, the finding of the analyses provides critical insights for SMEs when they are challenged to incorporate environmental issues.

It was also found that using diverse external information sources helped SMEs meet the market demands of environmentally innovative products in support of Hypothesis $2 \mathrm{~b}$. As environmental concerns tend to be raised by various external stakeholders, SMEs would perhaps be constrained to deal with such complex issues if they remained within their boundaries in terms of knowledge acquisition $[28,29,45]$. More specifically, rather than relying on limited numbers of knowledgeable partners, reaching out to diverse external partners enables SMEs to acquire non-redundant information relevant to the tasks of developing environmentally innovative products. The social network perspective always emphasizes the importance of diverse external ties through which non-redundant information may flow $[25,26]$. Such diverse sources of information located outside of the company are likely to enhance SMEs' capacity to deal with complex issues like environmental innovations. That is, to properly cope with environmental demands from the market, SMEs should recognize the importance of developing relationships with diverse partners from outside.

Regarding the findings about governmental supports, it seems very interesting that Hypothesis 3 a is not supported by the analyses. According to the argument developed in new-institutional theory, organizations may try to decouple their actual practices from what is institutionally required when they find a gap between the institutionally established ideas and their current efficient activities. That is, an organization may claim to the outside that it abides by the institutional pressure, but actually maintains its existing practices inside [15,19]. As scholars of new-institutional theory point out [16], environmental issues tend to fall in such institutional pressures that organizations cannot easily find an immediate fit for with their existing practices. Based on this idea of decoupling, it can be interpreted that the insignificant relationship between monetary support by the government and the SMEs' environmental innovations in the analysis is because regardless of their actual capacity to perform the requirements, SMEs have rational motivations to receive monetary support from the government in advance by superficially complying with what the government guides. It may also take longer for SMEs that do not prepare for immediate technological responses to the environmental requirements to sufficiently incorporate governmental monetary support regarding environmental concerns into the actual outcomes without technological capabilities. In such situations, SMEs would take decoupling positions in terms of governmental requests 
for environmental innovation for a while, until they appropriately transform the monetary support into visible outcomes [19]. While the monetary support from the government does not have a significant relationship with environmental innovative outcomes, the technological supports from government do actually affect SMEs' environmental innovations. Regarding such findings about the governmental factors, it would be interpreted that the policymakers would employ more specifically developed technological support systems to encourage SMEs to accelerate the environmental innovations rather than simple monetary support.

\section{Conclusions}

This paper provides theoretically noteworthy contributions as well as managerially meaningful implications. First of all, the study contributes to the literature of SMEs' environmental innovation by emphasizing the significance of considering various, yet distinctive domains in which solid theoretical insights from organization theories can be effectively applied [6]. To date, a primary driving force of SMEs' environmental accomplishments has been discussed mostly based upon the natural resource-based view in which how the resources and the environment are effectively connected is addressed. However, a closer explanation of how the environment may come into the actual process of utilizing resources has not been sufficiently addressed. By examining three distinctive domains with three theoretical frameworks developed in the area of organization theory, this study provides more detailed explanation about SMEs' environment-related strategies.

The findings confirm the importance of appropriate financial investments on both internal and external innovation-related activities in efforts to enhance SMEs' capabilities of environmental innovations. As the resource-based view of the firm suggests, strategic competitive advantages residing in unique resources and inimitable capabilities can be acquired only when a company sets appropriate investment plans with strategic focuses $[7,8]$. To enhance the capabilities incorporating the environmental concerns raised by the crucial stakeholders from outside, an SME should allocate its financial resources in directions to strengthen the areas of management in which the intended outcomes can be effectively pursued. Thus, the study reconfirms the relevance of the natural resource-based view (NRBV)'s suggestions that a company preparing constantly for the innovations can build its own resources and capabilities to deal with environmental issues raised by consumers. In doing so, this study contributes to the literature of SMEs' environmental innovation by theoretically incorporating the NRBV's arguments [2,3].

The result of the analysis that an SME experiencing success in other innovative areas tends to produce environmentally innovative products is also well-aligned with the consistent arguments of organizational learning theory that cumulated experiences of success lead to subsequent success in other areas $[10,11]$. The findings show that to make a noticeable innovative performance, an SME should make great efforts to draw more successful experiences in other technological areas and combine such successful experiences with a specifically focused target area. Considering that SMEs tend to be under relatively disadvantageous conditions to accumulate successful experiences, organizational learning literature provides a useful insight that the success experience in an area can be nicely transferred into other areas when SMEs pay strategic attentions to their overall innovation activities. Therefore, the current study expands the applications of well-accepted arguments from organizational learning theory to the area of SMEs' innovation activities.

Through an in-depth analysis, this study also shows that diverse information sources help SMEs generate the environmental innovate on outcomes. Such a finding links the long-standing arguments of social network theory as well as the knowledge management area with the SMEs' environmental innovation activities [27-32]. Environmental concerns raised by various external stakeholders may be difficult for SMEs to deal with if they remain within their boundaries in searching for solutions. As social network theory and knowledge management concurrently suggest, reaching out to diverse external partners helps SMEs acquire useful non-redundant information more effectively than relying on limited numbers of knowledgeable partners $[27,30]$. The finding regarding the impact of diversity 
of external information sources, therefore, provides important implications to the existing literature of SMEs' environmental innovations.

The finding about the governmental supports for SMEs invites the new-institutional theory to an in-depth discussion. As the findings show, technological support received from the government has significant impacts on SMEs' environmental innovation, while monetary support does not. Considering that companies are exposed to governmental pressures about the environmental problems, the variation of behavioral outcomes of SMEs produced by governmental policies should be investigated more, so that environmental policies regarding the SMEs' innovation activities can be more effectively articulated. As discussed in the Discussion section, SMEs may employ decoupling strategies when they face rather coercive pressures about environmental issues $[16,19]$. Through new-institutional interpretations of the result, this study lays a stepping stone by which further investigations about the influences of government-driven policies on the SMEs' environmental innovations may be carried out.

In addition to the theoretical contributions, this study also provides some strategic implications. Innovation is critical for SMEs to cope with the rapidly emerging environmental concerns from various stakeholders especially in a constantly competitive market environment. Given such economic and social environments surrounding SMEs, the market introduction of environmentally innovative products is a significant strategic option that an SME must choose to deal with both the existing market competition and the environmental concerns. In particular, through an in-depth investigation of crucial factors from three distinctive domains, this study helps the decision-makers of SMEs understand how they allocate their strategic attentions to each domain to enhance their chances of successfully introducing environmentally innovative new products. Furthermore, this study also provides an important insight especially for the government, the most crucial policy maker of environment-related policies affecting private companies; the finding that non-monetary technological support by the government has a significant and positive relationship with the SMEs' environmental innovations gives noteworthy insights to the government when it attempts to extend the intended outcomes of SMEs across various industries. Rather than simple monetary supports, well-designed technological supports would provide more benefits to all the social and economic stakeholders by encouraging private companies to focus on the environmental issues more effectively.

Despite the discussed contributions, this study has some limitations that are mostly derived from the features of the dataset used in analysis. The dataset used in this study may be challenged by those who have concerns about its survey-based features. The survey method is often criticized about its reliability of responses as the data collected by self-reports may result in biases in the process of data collection, such as a socially desirable response bias. In addition to the potential problems derived from socially desirable responses, the responses to survey questions are also criticized because the answers tend to be subjective, rather than objective. Although the KIS was made based on the survey developed by a world-wide consensus and this survey-based data has been widely used for existing studies for organizational innovations, the use of the survey data may be indicated as a weak part of this study. In addition, considering that the environmental issues are being considered as world-wide concerns, some may point out that the use of data collected in a single country may be also a downside of this study. Thus, a dataset constructed by combining the data of other countries would enhance the generalizability of the findings. Lastly, a systematically collected longitudinal data of organizations' environmental innovation activities should be considered to assure the causal relationships over time between the variables. In future studies, using innovation-related data that are more systematically collected using objectively quantifiable measurements from more than several key countries would help overcome such limitations.

Funding: This research was supported by a grant from Kyung Hee University in 2014 (KHU-20140696).

Conflicts of Interest: The author declares no conflict of interest. 


\section{References}

1. Berrone, P.; Fosfuri, A.; Gelabert, L.; Gomez-Mejia, L.R. Necessity as the mother of 'green' inventions: Institutional pressures and environmental innovation. Strat. Manag. J. 2013, 34, 891-909. [CrossRef]

2. Hart, S.L. A natural-resource-based view of the firm. Acad. Manag. Rev. 1995, 20, 986-1014. [CrossRef]

3. Hart, S.L.; Bowell, G. A natural-resource-based view of the firm: Fifteen years after. J. Manag. 2011, 37, 1464-1479.

4. Chialin, C. Design for the environment: A quality-based model for green product development. Manag. Sci. 2001, 47, 250-263.

5. Horbach, J. Determinants of environmental innovation-New evidence from German panel data sources. Res. Policy 2008, 37, 163-173. [CrossRef]

6. Del Brìo, J.A.; Junquera, B. A review of the literature on environmental innovation management in SMEs: implications for public policies. Technovation 2003, 23, 939-948. [CrossRef]

7. Barney, J.B. Firm resources and sustained competitive advantage. J. Manag. 1991, 17, 99-120. [CrossRef]

8. Penrose, E. The Theory of The Growth of The Firm; Wiley: New York, NY, USA, 1959.

9. Seo, H.; Chung, Y.; Woo, C.; Chun, D.; Jang, S.S. SME's appropriability regime for sustainable development-the role of absorptive capacity and inventive capacity. Sustainability 2016, 8, 665. [CrossRef]

10. Argote, L. Organizational Learning: Creating, Retaining and Transferring Knowledge; Springer Science \& Business Media: New York, NY, USA, 2012.

11. Argote, L.; Miron-Spektor, E. Organizational learning: From experience to knowledge. Organ. Sci. 2011, 22, 1123-1137. [CrossRef]

12. Burt, R.S. Brokerage and Closure: An Introduction to Social Capital; Oxford University Press: New York, NY, USA, 2005.

13. Kilduff, M.; Tsai, W. Social Networks and Organizations; SAGE Publications: Thousand Oaks, CA, USA, 2003.

14. Cross, R.; Thomas, R.J. Driving Results Through Social Networks: How Top Organizations Leverage Networks for Performance and Growth; Jossey-Bass: San Francisco, CA, USA, 2009.

15. Meyer, J.W.; Rowan, B. Institutionalized organizations: Formal structure as myth and ceremony. Am. J. Sociol. 1977, 83, 340-363. [CrossRef]

16. DiMaggio, P.; Powell, W.W. The iron cage revisited: Collective rationality and institutional isomorphism in organizational fields. Am. Sociol. Rev. 1983, 48, 147-160. [CrossRef]

17. Cohen, W.M.; Levinthal, D.A. Absorptive capacity: A new perspective on learning and innovation. Admin. Sci. Quart. 1990, 35, 128-152. [CrossRef]

18. Hansen, M.T. The search-transfer problem: The role of weak ties in sharing knowledge across organization subunits. Admin. Sci. Quart. 1999, 44, 82-111. [CrossRef]

19. Boxenbaum, E.; Jonsson, S. Isomorphism, diffusion and decoupling: Concept evolution and theoretical challenges. In The Sage Handbook of Organizational Institutionalism; Greenwood, R., Oliver, C., Sahlin, K., Suddaby, R., Eds.; Sage Publications: London, UK, 2018; pp. 79-104.

20. Ocasio, W. Towards an attention-based view of the firm. Strat. Manag. J. 1997, 18, 187-206. [CrossRef]

21. Ocasio, W. Attention to attention. Org. Sci. 2011, 22, 1286-1296. [CrossRef]

22. March, J.G. A Primer on Decision Making: How Decisions Happen; The Free Press: New York, NY, USA, 1994.

23. March, J.G. Exploration and exploitation in organizational learning. Org. Sci. 1991, 2, 71-87. [CrossRef]

24. Zollo, M.; Reuer, J.J. Experience spillovers across corporate development activities. Org. Sci. 2010, 21, 1195-1212. [CrossRef]

25. Burt, R.S. Structural Holes: The Social Structure of Competition; Harvard University Press: Boston, NJ, USA, 1992.

26. Podolny, J.M. Networks as the pipes and prisms of the market. Am. J. Sociol. 2001, 107, 33-60. [CrossRef]

27. Reagans, R.; McEvily, B. Network structure and knowledge transfer: The effects of cohesion and range. Admin. Sci. Quart. 2003, 48, 240-267. [CrossRef]

28. Easterby-Smith, M.; Lyles, M.A.; Tsang, E.W. Inter-organizational knowledge transfer: Current themes and future prospects. J. Manag. Stud. 2008, 45, 677-690. [CrossRef]

29. Van Wijk, R.; Jansen, J.J.; Lyles, M.A. Inter-and intra-organizational knowledge transfer: a meta-analytic review and assessment of its antecedents and consequences. J. Manag. Stud. 2008, 45, 830-853. [CrossRef]

30. Simao, L.; Franco, M. External knowledge sources as antecedents of organizational innovation in firm workplaces: a knowledge-based perspective. J. Knowl. Manag. 2018, 22, 237-256. [CrossRef] 
31. Mol, M.J.; Birkinshaw, J. The role of external involvement in the creation of management innovations. Organ. Stud. 2014, 35, 1287-1312. [CrossRef]

32. Mol, M.J.; Birkinshaw, J. The sources of management innovation: when firms introduce new management practices. J. Bus. Res. 2009, 62, 1269-1280. [CrossRef]

33. Hoffman, A.J.; Jennings, P.D. Institutional theory and the natural environment: Research in (and on) the Anthropocene. Org. Env. 2015, 28, 8-31. [CrossRef]

34. Korea Innovation Survey. Available online: http://www.stepi.re.kr/kis/service/sub02_data_application.do (accessed on 25 January 2019).

35. Yang, D.; Park, S. Too much is as bad as too little? Sources of the intention-achievement gap in sustainable innovation. Sustainability 2012, 8, 712. [CrossRef]

36. Woo, C.; Chung, Y.; Chun, D.; Han, S.; Lee, D. Impact of green innovation on labor productivity and its determinants: An analysis of the Korean manufacturing industry. Bus. Strat. Env. 2014, 1, 567-576. [CrossRef]

37. Chun, D.; Chun, Y.; Woo, C.; See, H.; Ko, H. Labor Union Effects on Innovation and Commercialization Productivity: An Integrated Propensity Score Matching and Two-Stage Data Envelopment Analysis. Sustainability 2015, 7, 5120-5138. [CrossRef]

38. Choi, H.; Yi, D. Environmental innovation inertia: Analyzing the business circumstances for environmental process and product innovations. Bus. Strat. Env. 2018, 1, 1-12. [CrossRef]

39. Castelllacci, F.; Lie, C.M. A taxonomy of green innovators: Empirical evidence from South Korea. J. Clean. Prod. 2017, 143, 1036-1047. [CrossRef]

40. Blau, P.M. Inequality and Heterogeneity: A Primitive Theory of Social Structure; The Free Press: New York, NY, USA, 1977.

41. Etzion, D. Research on organizations and the natural environment, 1992-present: A review. J. Manag. 2007, 33, 637-664. [CrossRef]

42. Christmann, P. Effects of "best practices" of environmental management on cost advantage: The role of complementary assets. Acad. Manag. J. 2000, 43, 663-680.

43. Tushman, M.L.; O'Reilly, C.A. The ambidextrous organizations: Managing evolutionary and revolutionary change. Calif. Manag. Rev. 1996, 38, 8-30. [CrossRef]

44. Szulanski, G. Exploring internal stickiness: Impediments to the transfer of best practice within the firm. Strateg. Manag. J. 1996, 17, 27-43. [CrossRef]

45. Teece, D.J. Technology transfer by multinational firms: The resource cost of transferring technological know-how. Econ. J. 1977, 87, 242-261. [CrossRef] 